
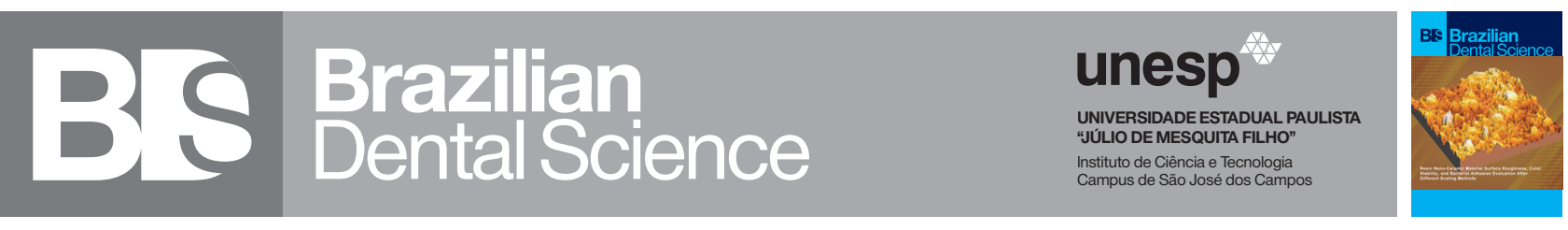

\title{
Risk factors of complications subsequent third molar extractions: A prospective cohort study
}

Fatores de risco de complicações subsequentes à extrações de terceiros molares: um estudo de coorte prospectivo

Dena ALI ${ }^{1}$

1 - Kuwait University, Faculty of Dentistry, Jabriya, Kuwait.

\section{ABSTRACT}

Objective: The aim of this study was to determine the complications that were associated with the surgical removal of third molars (M3s), and to assess the association of patient, anatomic, and surgical risk factors with the postoperative complications of surgically removed impacted M3s. Material and Methods: This study was a cohort prospective study conducted on patients, aged 17 and older, admitted to the oral and maxillofacial surgery clinic. All patients who needed 1 or more extractions were included and totalled 268 patients with 314 extracted teeth. Risk factors were divided into patient factors, anatomic factors and surgical factors. The postoperative complication variables mainly included: pain, alveolar osteitis, infection, bleeding, swelling, trismus. Statistical analysis used: Chi-square test was used for the bivariate analyses while Pearson correlation coefficient (1- tailed) test was used for the purpose of determining the association between the study variables. The significance of associations was considered statistically significant at $\mathrm{p}<0.05$. Results: Patients aged of 25 years and above experienced more complications, 39 (88.6\%). With respect to gender, females experienced more complications, 29 (65.9\%). Mandibular M3s had more complications than maxillary M3s, 34 (8.0\%), followed by distoangular inclined M3s, $23(52.3 \%)$, and last was full bony impaction, 13 (29.5\%). Pain was the most frequent complication, $18(40.9 \%)$, followed by alveolar osteitis 12 (27.3\%). Conclusion: The results indicated that the most frequently complications were pain, infection, alveolar osteitis. These complications were associated with common risk factors such as age, gender, medical history, M3 angulation, impaction level, bone removal, tooth sectioning, and number of M3 removed per session.

\section{KEYWORDS}

Complications; Surgical extraction; Third molar.

\section{RESUMO}

Objetivo: O objetivo deste estudo foi determinar as complicações que estavam associadas à cirurgia de remoção dos terceiros molares (3Ms) e avaliar a associação dos fatores de risco do paciente, anatômicos e cirúrgicos com as complicações pós-operatórias dos 3Ms impactados removidos cirurgicamente. Material e Métodos: Esse estudo foi um estudo de coorte prospectivo realizado em pacientes com idade igual ou superior a 17 anos, admitidos na clínica de cirurgia oral e maxilofacial. Todos os pacientes que precisaram de uma ou mais extrações foram incluídos, totalizando 268 pacientes e 314 dentes extraídos. Os fatores de risco foram divididos em fatores do paciente, fatores anatômicos e fatores cirúrgicos. As variáveis de complicações pós-operatórias incluíram principalmente: dor, osteíte alveolar, infecção, sangramento, edema, trismo. Análise estatística utilizada: o teste de Qui-quadrado foi utilizado para as análises bivariadas enquanto o teste do coeficiente de correlação de Pearson (unicaudal) foi usado para determinar a associação entre as variáveis do estudo. A significância das associações foi considerada estatisticamente significativa para $p$ $<0,05$. Resultados: Pacientes com 25 anos ou mais apresentaram mais complicações (39; 88,6\%). Com relação ao gênero, o sexo feminino apresentou mais complicações (29; 65,9\%). 3Ms mandibulares tiveram mais complicações do que 3Ms maxilares (34; 8,0\%), seguidos por 3Ms com inclinação distoangulada (23; $52,3 \%)$ e, por último, com impactação óssea total (13; 29,5\%). Dor foi a complicação mais frequente (18; 40,9\%), seguida de osteíte alveolar (12; $12,3 \%)$. Conclusão: Os resultados indicaram que as complicações mais frequentes foram dor, infecção, osteíte alveolar. Essas complicações foram associadas a fatores de risco comuns, como idade, sexo, histórico médico, angulação do 3M, nível de impactação, remoção de osso, secção dentária e número de 3Ms removidos por sessão.

\section{PALAVRAS-CHAVE}

Complicações; Extração cirúrgica; Terceiro molar. 


\section{INTRODUCTION}

$\Pi$ he removal of third molars (M3s) is one $\perp$ of most common procedures practiced in oral and maxillofacial surgery clinics. [1] This procedure is frequently associated with complications including pain, bleeding, swelling, alveolar osteitis, infection, trismus, oro-antral communication, and infrequently associated with fracture of the mandible and/ or maxillary tuberosity and paraesthesia of the inferior alveolar and/or lingual nerves. [2,3]

These complications have been reported to range from minor distress to more complicated outcomes. However, most of these complications are transitory, if managed properly; therefore, identifying and estimating these complications and reducing their severity is regarded as one of the primary responsibilities of oral and maxillofacial surgeons. [4] Hence, patients must be given detailed information with regard to the risks and complications that may be associated with surgical removal of M3s. [5]

Previous literature has reported multiple factors associated with post-operative complications. Patient related factors include age, gender, smoking, oral contraceptive use, and the presence of comorbid medical conditions. [6,7] Factors related to anatomy include M3 angulation, level of impaction (soft tissue, partial, and full bony), and number of teeth to be extracted. $[2,3,8]$

It is projected that dental practitioners would benefit from knowing the risk factors that are linked with postoperative complications of M3s surgical extraction. This knowledge will empower practitioners to evade subjecting patients to such complications while carrying out M3 removal surgery. Thus, the aim of this study was to establish the occurrence of complications that were associated with the surgical removal of M3s, and to assess the association of patient, anatomic, and surgical risk factors with the postoperative complications of impacted M3 surgical removal.

\section{MATERIALS AND METHODS}

This study was a cohort prospective study that was conducted at Kuwait University Faculty of Dentistry, Department of Oral and Maxillofacial clinic. This study was conducted in full accordance with the World Medical Association Declaration of Helsinki and was approved by the Ethics Committee of the Health Sciences Center at Kuwait University, reference no. VDR/EC/3551. The patient pool was derived from patients admitted to the oral and maxillofacial surgery clinic for evaluation and treatment of impacted maxillary and mandibular M3s from January 2019 to December 2019. Age criteria was 17 years and older. Medical history of all patients was checked according to the American Society of Anesthesiologists (AHA), grade I and II (ASA I \&II) were recruited in this study. Exclusion criteria included ASA III-VI patients, extensive pathological lesions, and patients who failed to report for follow up appointments. Extractions were completed by full time oral and maxillofacial surgeons, who followed strict aseptic sterile technique and surgical extraction protocols. Detailed informed consent forms were reviewed and obtained from all study participants following a thorough discussion regarding risks, benefits and alternatives to the procedure.

All procedures were carried out in the oral and maxillofacial surgery clinic under strict aseptic protocol. Local anaesthesia was administered (3\% lidocaine with noradrenalin at 1:50,000) for all M3 extraction procedures. For maxillary M3s extraction procedures, regional blocking of the greater palatine and posterior superior alveolar nerves after aspiration was utilized. As for mandibular M3s, regional blocking of the lower inferior alveolar, lingual, and buccal nerves after aspiration was used. No sedation method was employed in the study. Surgical high-speed handpieces $(80,000-$ $150,000 \mathrm{rpm}$, taper/flat end cross cut no. $703)$ and sterile saline solution $(0.9 \%$ sodium 
chloride concentration) were used for bone removal and tooth sectioning when necessary. Minnesota retractor was used for retraction and tissue protection. Wound closed with 3-0 silk sutures which were removed 5 days later. All extractions were carried out according to the standardized general method for the surgical removal of impacted maxillary and mandibular M3s described by Farish and Bouloux. [9]

Five-day postoperative antibiotic regimen (intraoral cephalexin $500 \mathrm{mg}$ ) was prescribed to patients who had difficult extraction (covered by bone) and in cases where the duration of surgery exceeded 30 minutes to reduce the incidence of alveolar osteitis. Analgesics (Ibuprofen 400mg) were prescribed postoperatively for pain management, to be taken when needed every 4-6 hours. [10,11] Post-surgical extraction instructions were given to patients in writing and orally. Post-surgical extraction instructions were intended to stop bleeding, reduce pain, and promote healing. The instructions included: Bite on a gauze pad firmly for 30-60 minutes for the first few hours, avoid spitting, sucking on candies or through a straw, abstain from smoking and tobacco use, avoid sneezing or coughing, avoid brushing or flossing next to the extraction site, refrain from alcoholic drinks and hot or carbonated beverages, and avoid hot or spicy food.

Two follow up appointments were planned; first appointment was within 5 to 6 days of the extraction day and the second follow up was at 4-6 weeks post extraction date.

The study variables that are foreseen to have an impact on the outcome of M3 surgical extraction were divided into patient, anatomic, and surgical risk factors. Patient factors included: age, gender, smoking, oral contraceptive use, controlled systemic diseases such as diabetes, hypertension, and asthma. Anatomic factors included: level of impaction (soft tissue, partial bony, or full bony), and angulation of M3 with respect of the longitudinal access of the adjacent second molars based on Winter's classification (mesioangular, distoangular, vertical, horizontal, reversed, others). [12] Surgical factors included: type of flap used (triangular and envelop), Bone removal involved, tooth sectioning, and number of extracted teeth per session. Post-operative complications were tested based on frequency of occurrence. The postoperative complication variables were divided into early complications that occurred within 4-5 days post operatively, detailed as followed: pain, alveolar osteitis, infection, bleeding, swelling, trismus, root tip fracture, fracture of the mandible (mandibular angle, tuberosity), oro-antral communication, and displacement of teeth into adjacent spaces. Late post-operative complications that occurred 4-6 weeks included sensory nerve injury (paraesthesia) and delayed infection. [13]

The Data collection process was conducted using Microsoft Excel spreadsheet, (Office 365 version 16.0, USA), and transferred to Statistical Package for Social Sciences (SPSS) version 20.0 (SPSS Inc., Chicago, IL, USA) for statistical analyses.

\section{Statistical analysis}

Chi-square test was used for the bivariate analyses while Pearson correlation coefficient (1- tailed) tests were used for the purpose of determining the association between the study variables. The significance of associations was considered statistically significant at $\mathrm{P}<0.05$.

\section{RESULTS}

Total number of enrolled patients was 273, however 5 patients failed to report for follow up appointments therefore they were excluded from the study. Out of 268 participants, 130 (48.5\%) were male patients, and 138 (51.5\%) were female patients. Age category of 17- 24 years was the highest among other categories, 101 (37.7\%), next was age 25- 30 years of age, 92 
(34.3\%). Participants aged above 40 years were the least in number, totalled 14 patients (5.2\%). All study participants were classified as ASA I and II, where 210 (78.4\%) participants were healthy without existing medical conditions (ASA I), 11 (4.1\%) were diagnosed with controlled diabetes and $9(3.4 \%)$ were hypertensive. Participants on oral contraceptives totalled $22(7.2 \%)$ and 10 patients had asthma (3.7\%). Smokers counted for 21(7.8). Detailed descriptive frequencies for patients' variables are presented in Table I.

Table I - Descriptive frequencies for patients' factors

\begin{tabular}{|ccc|}
\hline Category & $\mathbf{n}$ & \% \\
\hline Age & & \\
\hline Age 17-24 & 101 & 37.7 \\
\hline Age 25-30 & 92 & 34.3 \\
\hline Age 31-35 & 34 & 12.7 \\
\hline Age 36-40 & 27 & 10.1 \\
\hline$>40$ & 14 & 5.2 \\
\hline Gender & & \\
\hline Male & 130 & 48.5 \\
\hline Female & 138 & 51.5 \\
\hline Medical History (ASAl) & & \\
\hline Diabetes & 11 & 4.1 \\
\hline Hypertension & 9 & 3.4 \\
\hline Smoking & 21 & 7.8 \\
\hline Asthma & 10 & 3.7 \\
\hline Oral contraceptive pills & 7 & 2.6 \\
\hline No Medical Problems & 210 & 78.4 \\
\hline
\end{tabular}

Three hundred and fourteen impacted M3s were surgically removed from 268 participants. The total number of impacted mandibular M3s was 198 (63.0\%) where the number of impacted maxillary M3s was 116 (37.0\%). With regard to M3 angulation, the most commonly represented Winter's impaction classification was mesioangular impaction, 127 (40.6\%), followed by vertical and distoangular, $114(36.3 \%)$ and $63(20.1 \%)$, respectively. With respect to the level of impaction, partial bony impaction was the most frequent, 151 (48.1\%), next was soft tissue impaction 144 (45.9\%), and last was full bony impaction, 19 (6.0\%). In reference to type of flap used, triangular flap was the most common flap used, 169 (53.7\%). Moreover, 63 (20.1\%) participants had impacted M3 sectioned intraoperatively and 51 (16.4\%) participants had more than one M3 removed. Table II summarizes the statistical frequencies for anatomical and surgical risk factors.

Table II - Statistical frequencies for anatomical and surgical risk factors

\begin{tabular}{|c|c|c|}
\hline Category & n & $\%$ \\
\hline \multicolumn{3}{|l|}{ Impaction type } \\
\hline *Max M3 impaction & 116 & 37 \\
\hline 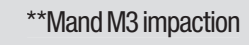 & 198 & 63 \\
\hline \multicolumn{3}{|l|}{ Winter's classifications } \\
\hline Mesioangular & 127 & 40.6 \\
\hline Distoangular & 63 & 20.1 \\
\hline Vertical & 114 & 36.3 \\
\hline Horizontal & 9 & 3 \\
\hline \multicolumn{3}{|l|}{ Level of impaction } \\
\hline Soft tissue & 144 & 45.9 \\
\hline Partial bony & 151 & 48.1 \\
\hline Full bony & 19 & 6 \\
\hline \multicolumn{3}{|l|}{ Type of flap } \\
\hline Triangular & 169 & 53.7 \\
\hline Envelop & 145 & 46.3 \\
\hline \multicolumn{3}{|l|}{ Bone removal } \\
\hline Yes & 108 & 34.3 \\
\hline No & 206 & 65.7 \\
\hline \multicolumn{3}{|l|}{ Tooth sectioning } \\
\hline Yes & 63 & 20.1 \\
\hline No & 251 & 79.9 \\
\hline \multicolumn{3}{|l|}{ No. of M3 removed } \\
\hline One tooth removed & 263 & 83.6 \\
\hline Two teeth removed & 49 & 15.7 \\
\hline Three teeth removed & 2 & 0.7 \\
\hline
\end{tabular}

With regard to postoperative complications, more than $80 \%$ of the sampled population did not have complications, 224 
(83.6\%) while 44 (16.4\%) had postoperative complications. Among all tested complications, pain was the most frequently reported complication, 18 (40.9\%), followed by alveolar osteitis 12 (27.3\%), and infection 5 (11.4\%). There were no delayed complications recorded during the interval of this study. A minimal number of cases were reported for bleeding, swelling, trismus, and root tip fracture, and no reported cases for a bony fracture (e.g., mandibular angle or maxillary tuberosity), oro-antral communication, sensory nerve injury (paraesthesia), or displacement of teeth into adjacent spaces. Figure 1 illustrates the frequency of postoperative complications among the sampled participants.

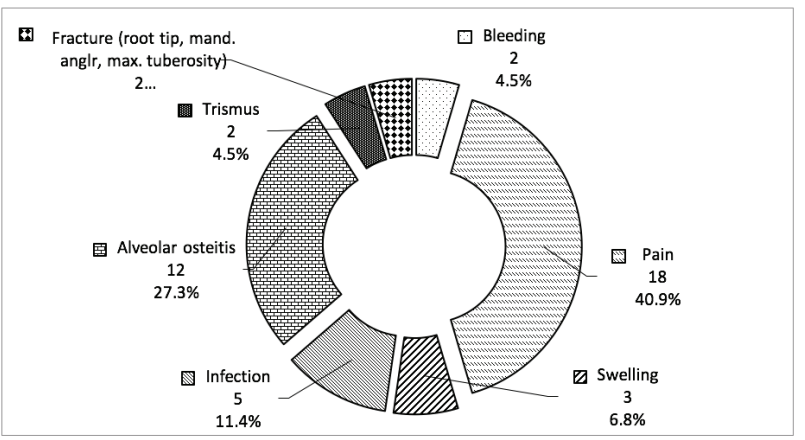

Figure 1 - Post operative complications distribution.

The statistical analysis of the study variables and postoperative complications revealed that patients aged of 25 years and above experienced more complications, 39 (88.6\%), than their younger counterparts. Female patients experienced more complications postoperatively than male patients, 29, (65.9\%). In addition, diabetic patients, $8(18.2 \%)$, and patients on oral contraceptives, $6(13.6 \%)$ were more frequent in developing postoperative complications. With respect to anatomical factors: mandibular M3s, 34 (8.0\%), distoangular inclined, 23 (52.3\%), and vertical M3s, 11 (25.0\%) had more complications. The level of impaction analysis showed that patients with a full bony impaction, 13 (29.5\%), and partial impaction, 25 (56.8\%), were more susceptible to complications than that of soft tissue impactions. In terms of surgical factors, patients who underwent a triangular flap, 26(59.1\%), bone removal, 38 (86.4\%) or tooth sectioning, 23 (52.3\%), were found to be associated with complications. Last, the number of teeth removed per session demonstrated that patients who had two M3s removed, had the highest frequency of complications, 29 (65.9\%). There were no reported cases with four M3s removed in one session. Table III illustrates cross factors association with postoperative complications.

The selected complications were tested for association with the patient, anatomic, and surgical risk factors at $\mathrm{P}<0.05$. The statistical outcome indicated that pain was significantly affected by multiple factors including: age $(\mathrm{p}=.002)$, gender $(\mathrm{p}=.001)$, medical history $(\mathrm{p}=.003)$, M3 angulation ( $\mathrm{p}=.028)$, level of impaction ( $\mathrm{p}$ $=.002)$, removal of bone $(\mathrm{p}=.022)$, and tooth sectioning $(\mathrm{p}=.005)$. Equally for postoperative infection, the tested associations were significant for gender ( $\mathrm{p}=.044)$, medical history $(\mathrm{p}=$ .022), impaction arch, maxilla vs. mandible ( $\mathrm{p}=$ $.004)$, M3 angulation $(\mathrm{p}=.026)$, flap type $(\mathrm{p}=$ $.032)$, bone removal ( $\mathrm{p}=.001)$, tooth sectioning $(\mathrm{p}=.011)$, and number of teeth removed $(\mathrm{p}=$ .014). Alveolar osteitis, however, demonstrated a significant association with all the tested variables except for level of impaction, and number of M3s removed. The significant association for alveolar osteitis was reported as follows, age $(\mathrm{p}=.022)$, gender ( $\mathrm{p}=.015)$, medical history $(\mathrm{p}=.042)$, arch of impaction ( $\mathrm{p}=.045), \mathrm{M} 3$ angulation $(\mathrm{p}=.008)$, flap type $(\mathrm{p}=.014)$, bone removal $(\mathrm{p}=.033)$, and tooth sectioning $(\mathrm{p}=.045)$. Table III demonstrated detailed bivariate association between the risk factors and postoperative complications.

A significant observation that is worth mentioning that there were five consistent risk factors associated with M3 surgical removal frequent complications. These factors were gender, medical history, M3 angulation, removal of bone, and tooth sectioning. Moreover, these factors had an overall significance of $\mathrm{P}<0.05$. 
Figure 1 - Post operative complications distribution.

\begin{tabular}{|c|c|c|c|c|c|c|c|c|c|c|c|c|c|c|c|c|c|c|c|c|c|c|c|c|}
\hline \multirow[b]{3}{*}{ Age } & \multicolumn{3}{|c|}{ Bleeding } & \multicolumn{3}{|c|}{ Pain } & \multicolumn{3}{|c|}{ Swelling } & \multicolumn{3}{|c|}{$\begin{array}{l}\text { Infec- } \\
\text { tion }\end{array}$} & \multicolumn{2}{|c|}{$\begin{array}{l}\text { Alveolar } \\
\text { Osteitis }\end{array}$} & \multicolumn{4}{|c|}{ Trismus } & \multicolumn{2}{|c|}{$\begin{array}{l}\text { Fracture (root } \\
\text { tip, mand. } \\
\text { Angle, max. } \\
\text { tuberosity) }\end{array}$} & \multicolumn{4}{|c|}{$\begin{array}{c}\text { Total } \\
\text { Complications }\end{array}$} \\
\hline & $\mathrm{n}$ & $\%$ & $p$ & $n$ & $\%$ & $p$ & $\mathrm{n}$ & $\%$ & $p$ & $n$ & $\%$ & $p$ & $n$ & $\%$ & $p$ & $n$ & $\%$ & $p$ & $n$ & $\%$ & $p$ & $n$ & $\%$ & $p$ \\
\hline & & & .286 & & & .002 & & & .311 & & & .081 & & & .022 & & & .018 & & & .442 & & & .001 \\
\hline Age 17-24 & 0 & 0.0 & & 2 & 4.5 & & 0 & 0.0 & & 1 & 2.3 & & 2 & 4.5 & & 0 & 0.0 & & 0 & 0.0 & & 5 & 11.4 & \\
\hline Age 25-30 & 0 & 0.0 & & 7 & 15.9 & & 2 & 4.5 & & 1 & 23 & & 3 & 6.8 & & 0 & 0.0 & & 2 & 4.5 & & 15 & 34.1 & \\
\hline Age $31-35$ & 0 & 0.0 & & 2 & 4.5 & & 0 & 0.0 & & 1 & 2.3 & & 2 & 4.5 & & 2 & 4.5 & & 0 & 0.0 & & 7 & 15.9 & \\
\hline Age36-40 & 1 & 2.3 & & 4 & 9.1 & & 1 & 2.3 & & 1 & 2.3 & & 5 & 11.4 & & 0 & 0.0 & & 1 & 2.3 & & 13 & 29.5 & \\
\hline$>40$ & 1 & 2.3 & & 3 & 6.8 & & 0 & 0.0 & & 0 & 0.0 & & 0 & 0.0 & & 0 & 0.0 & & 0 & 0.0 & & 4 & 9.1 & \\
\hline Gender & & & .050 & & & .001 & & & .021 & & & .044 & & & .015 & & & .060 & & & .067 & & & «.001 \\
\hline Male & 2 & 4.5 & & 6 & 13.6 & & 0 & 0.0 & & 2 & 4.5 & & 4 & 9.1 & & 1 & 2.3 & & 0 & 0.0 & & 15 & 34.1 & \\
\hline Female & 0 & 0.0 & & 12 & 27.3 & & 3 & 6.8 & & 2 & 4.5 & & 8 & 18.2 & & 1 & 2.3 & & 3 & 6.8 & & 29 & 65.9 & \\
\hline Medical History (ASAI\&ll) & & & .044 & & & .003 & & & .072 & & & .022 & & & .042 & & & .056 & & & .347 & & & .002 \\
\hline Diabetes & 1 & 2.3 & & 4 & 9.1 & & 0 & 0.0 & & 0 & 0.0 & & 1 & 2.3 & & 0 & 0.0 & & 2 & 4.5 & & 8 & 18.2 & \\
\hline Hypertension & 0 & 0.0 & & 0 & 0.0 & & 1 & 2.3 & & 1 & 2.3 & & 0 & 0.0 & & 0 & 0.0 & & 0 & 0.0 & & 2 & 4.5 & \\
\hline Smoking & 0 & 0.0 & & 0 & 0.0 & & 0 & 0.0 & & 1 & 2.3 & & 1 & 2.3 & & 0 & 0.0 & & 0 & 0.0 & & 2 & 4.5 & \\
\hline Asthma & 0 & 0.0 & & 0 & 0.0 & & 0 & 0.0 & & 0 & 0.0 & & 1 & 2.3 & & 0 & 0.0 & & 0 & 0.0 & & 1 & 2.3 & \\
\hline Oral contraceptive pills & 1 & 23 & & 3 & 6.8 & & 0 & 0.0 & & 0 & 0.0 & & 2 & 4.5 & & 0 & 0.0 & & 0 & 0.0 & & 6 & 13.6 & \\
\hline No Medical Problems & 0 & 0.0 & & 11 & 25.0 & & 2 & 4.5 & & 2 & 4.5 & & 7 & 15.9 & & 2 & 4.5 & & 1 & 2.3 & & 25 & 56.8 & \\
\hline Impaction arch & & & .081 & & & .073 & & & .021 & & & .004 & & & .045 & & & .232 & & & .920 & & & .072 \\
\hline Max & 2 & 4.5 & & 5 & 11.4 & & 0 & 0.0 & & 0 & 0.0 & & 2 & 4.5 & & 1 & 2.3 & & 0 & 0.0 & & 10 & 0.2 & \\
\hline Mand & 0 & 0.0 & & 13 & 29.5 & & 3 & 6.8 & & 4 & 9.1 & & 10 & 22.7 & & 1 & 23 & & 3 & 6.8 & & 34 & 0.8 & \\
\hline Winter's classifications & & & .005 & & & .028 & & & .334 & & & .026 & & & .008 & & & .050 & & & .061 & & & .006 \\
\hline Mesioangular & 2 & 4.5 & & 2 & 4.5 & & 0 & 0.0 & & 1 & 2.3 & & 3 & 6.8 & & 2 & 4.5 & & 0 & 0.0 & & 10 & 22.7 & \\
\hline Distoangular & 0 & 0.0 & & 10 & 22.7 & & 2 & 4.5 & & 3 & 6.8 & & 7 & 15.9 & & 0 & 0.0 & & 1 & 2.3 & & 23 & 52.3 & \\
\hline Vertical & 0 & 0.0 & & 6 & 13.6 & & 1 & 23 & & 0 & 0.0 & & 2 & 4.5 & & 0 & 0.0 & & 2 & 4.5 & & 11 & 25.0 & \\
\hline Horizontal & 0 & 0.0 & & 0 & 0.0 & & 0 & 0.0 & & 0 & 0.0 & & 0 & 0.0 & & 0 & 0.0 & & 0 & 0.0 & & 0 & 0.0 & \\
\hline Level of impaction & & & .062 & & & .002 & & & .032 & & & .062 & & & .073 & & & .022 & & & .052 & & & .003 \\
\hline Soft tissue & 1 & 2.3 & & 3 & 6.8 & & 0 & 0.0 & & 0 & 0.0 & & 0 & 0.0 & & 0 & 0.0 & & 2 & 4.5 & & 6 & 13.6 & \\
\hline Partial bony & 0 & 0.0 & & 11 & 25.0 & & 1 & 2.3 & & 2 & 4.5 & & 8 & 18.2 & & 2 & 4.5 & & 1 & 2.3 & & 25 & 56.8 & \\
\hline Full bony & 1 & 2.3 & & 4 & 9.1 & & 2 & 4.5 & & 2 & 4.5 & & 4 & 9.1 & & 0 & 0.0 & & 0 & 0.0 & & 13 & 29.5 & \\
\hline Type of flap & & & .098 & & & .623 & & & .068 . & & & .032 & & & .014 & & & .728 & & & .121 & & & .218 \\
\hline Triangular & 1 & 2.3 & & 8 & 18.2 & & 3 & 6.8 & & 4 & 9.1 & & 9 & 20.5 & & 1 & 2.3 & & 0 & 0.0 & & 26 & 59.1 & \\
\hline Envelop & 1 & 2.3 & & 10 & 22.7 & & 0 & 0.0 & & 0 & 0.0 & & 3 & 6.8 & & 1 & 2.3 & & 3 & 6.8 & & 18 & 40.9 & \\
\hline Bone removal & & & .042 & & & .022 & & & .001 & & & .001 & & & .033 & & & .004 & & & .036 & & & .005 \\
\hline Yes & 2 & 4.5 & & 14 & 31.8 & & 3 & 6.8 & & 4 & 9.1 & & 12 & 27.3 & & 2 & 4.5 & & 1 & 2.3 & & 38 & 86.4 & \\
\hline No & 0 & 0.0 & & 4 & 9.1 & & 0 & 0.0 & & 0 & 0.0 & & 0 & 0.0 & & 0 & 0.0 & & 2 & 4.5 & & 6 & 13.6 & \\
\hline Tooth sectioning & & & .040 & & & .005 & & & .022 & & & .011 & & & .045 & & & .002 & & & .307 & & & .012 \\
\hline Yes & 1 & 2.3 & & 7 & 15.9 & & 3 & 6.8 & & 3 & 6.8 & & 8 & 18.2 & & 1 & 2.3 & & 0 & 0.0 & & 23 & 52.3 & \\
\hline No & 1 & 2.3 & & 11 & 25.0 & & 0 & 0.0 & & 1 & 2.3 & & 4 & 9.1 & & 1 & 2.3 & & 3 & 6.8 & & 21 & 47.7 & \\
\hline No. of M3 removed & & & .078 & & & .081 & & & .061 & & & .014 & & & .078 & & & .034 & & & .024 & & & .002 \\
\hline One tooth removed & 1 & 2.3 & & 3 & 6.8 & & 0 & 0.0 & & 4 & 9.1 & & 5 & 11.4 & & 1 & 2.3 & & 0 & 0.0 & & 14 & 31.8 & \\
\hline Two teeth removed & 1 & 2.3 & & 15 & 34.1 & & 3 & 6.8 & & 0 & 0.0 & & 6 & 13.6 & & 1 & 2.3 & & 3 & 6.8 & & 29 & 65.9 & \\
\hline Three teeth removed & 0 & 0.0 & & 0 & 0.0 & & 0 & 0.0 & & 0 & 0.0 & & 1 & 2.3 & & 0 & 0.0 & & 0 & 0.0 & & 1 & 2.3 & \\
\hline
\end{tabular}

Bold text indicates statistically significant values.

$P$ - value is significant at $<0.05$ 


\section{DISCUSSION}

This study has demonstrated that there were several factors positively associated with complications after surgical removal of impacted M3s. The results verified that participants aged 25 years and older experienced more complications. This finding is coherent with the findings of Bruce et al. Chiapasco et al. and Capuzzi et al. [5,14-16] These authors attributed this finding to greater bone density in individuals above 25 years of age, resulting in more difficulty in the surgical removal of M3 and, thus, more complications than that of younger individuals. Besides, bone regeneration and healing capacity are slower in older population.

Female participants reported a higher rate of complications than males, parallel to the findings of Blondeau et al. and Lago-Méndez et al. in their studies. [2,17] This finding was associated with differences in pain tolerance, hormonal variations, and limited jaw size. Our study findings showed that diabetic patients and patients on oral contraceptives experienced more complications, which concurs with the results of previous studies. $[7,18,19]$ The literature has validated a positive association between oral contraceptives and postoperative complications due to the interferences with the healing process. Diabetes is a condition also known for compromised healing due to blood circulation deficit, which is associated with M3 removal complications. [20]

With respect to anatomical factors, bony impacted mandibular M3s with distal inclination had more frequent postoperative complications, which can be correlated with the procedure difficulty associated with the extraction. Our study findings are supported by the findings by ChaparroAvendaño et al. and Chuang SK et al. [21,22] suggesting that anatomical factors are directly related to post-operative complications as more surgical time is usually required for distally inclined and full bony impacted M3s.

Postoperative complications, that were noted to have an association with surgical factors, included the use of a triangular flap, bone removal, tooth sectioning, and number of M3s removed. These findings are coherent with that of Malakawi Z et al. [23] who found that lengthy procedures due to number of extracted teeth, amount of bone removal, triangular flap use, teeth sectioning are among the risk factors for M3 post extractions complications. On the contrary, Fisher et al. have inveterate opposing views. [24] Other complications that were mentioned by De Biase et al that were not assessed in this study included the development of a periodontal pocket distal to the second molar that could delay the healing, and the bacterial colonization at the extraction socket that might lead to secondary abscesses formation. [25]

One of the drawbacks of the study is that there was potential observer bias with regards to reporting complications by the patients. For instance, pain, as a post-operative complication, was self-reported by the patient which left a wide margin for over/under estimation for reporting pain. In addition, the absence of measuring time per extraction session would have provided more insight to the study outcome.

The study results showed that pain, alveolar osteitis, and infection were among the most frequently observed post-operative complications. The statistical analysis demonstrated that these complications share similar common risk factors including gender, medical history, M3 angulation, removal of bone, and tooth sectioning, which were statistically significant $(\mathrm{p}<0.05)$. We postulate that these factors should be taken into consideration prior to M3 extraction procedures to adequately counsel patients by anticipating and discussing relevant risk factors and to minimize post-operative complications.

\section{CONCLUSION}

Our results demonstrate that the most frequently reported complications were pain, infection, alveolar osteitis. These complications were associated with risk factors such as age, gender, medical history, M3 angulation, impaction 
level, bone removal, tooth sectioning, and number of M3 removed per session. The postoperative morbidity of M3 removal should be assessed prior to the procedure for risk stratification to anticipate the likelihood of post-operative complications. We advocate that clinicians be cognizant of these risk factors for M3 removal during treatment planning to improve post-operative outcomes and patient care. The authors suggest a national project to further explore risk factors associated with surgical removal of M3s.

\section{Acknowledgements}

The author would like to acknowledge Dr. Jessica S. Lee for her support and guidance.

\section{Financial disclosure}

Nil

\section{Conflict of interest}

The author declares no conflict of interest

\section{List of abbreviations}

M3: Third molar

\section{REFERENCES}

1. Shepherd JP, Brickley M. Surgical removal of third molars. Bmj.1994;309(6955):620-1.

2. Blondeau F, Daniel NG. Extraction of impacted mandibular third molars: postoperative complications and their risk factors. J Can Dent Assoc. 2007;73(4):325.

3. Bouloux GF, Steed MB, Perciaccante VJ. Complications of third molar surgery. Oral Maxillofac Surg Clin North Am. 2007;19(1):117-28, vii.

4. de Boer MP, Raghoebar GM, Stegenga B, Schoen PJ, Boering G. Complications after mandibular third molar extraction. Quintessence Int.1995;26(11):779-84.

5. Benediktsdóttir IS, Wenzel A, Petersen JK, Hintze H. Mandibular third molar removal: risk indicators for extended operation time, postoperative pain, and complications. Oral Surg Oral Med Oral Pathol Oral Radiol Endod. 2004;97(4):438-46.

6. Garcia AG, Grana PM, Sampedro FG, Diago MP, Rey JM. Does oral contraceptive use affect the incidence of complications after extraction of a mandibular third molar? Br Dent J. 2003;194(8):453-5; discussion 45.

7. Sisk AL, Hammer WB, Shelton DW, Joy ED, Jr. Complications following removal of impacted third molars: the role of the experience of the surgeon. J Oral Maxillofac Surg. 1986;44(11):855-9.
8. Chukwuneke F, Onyejiaka N. Management of postoperative morbidity after third molar surgery: a review of the literature. Niger J Med. 2007:16(2):107-Farish SE, Bouloux GF. General technique of third molar removal. Oral Maxillofac

9. Surg Clin North Am. 2007;19(1):23-43.

10. Mehrabi M, Allen JM, Roser SM. Therapeutic agents in perioperative third molar surgical procedures. Oral Maxillofac Surg Clin North Am. 2007 Feb;19(1):69-84.

11. Al-Asfour A. Postoperative infection after surgical removal of impacted mandibular third molars: an analysis of 110 consecutive procedures. Med Princ Pract. 2009;18(1):48-52

12. Winter GB. The Principals of exodontia as applied to the impacted thirc molar. St. Louis (MO): American Medical Book Co;1926.

13. Di Nardo D, Mazzucchi G, Lollobrigida M, Passariello C, Guarnieri R, Galli M, et al. Immediate or delayed retrieval of the displaced third molar: A review. J Clin Exp Dent. 2019 Jan 1;11(1):e55-e61.

14. Chiapasco M, De Cicco L, Marrone G. Side effects and complications associated with third molar surgery. Oral Surg Oral Med Oral Pathol. 1993;76(4):412-20.

15. Capuzzi P, Montebugnoli L, Vaccaro MA. Extraction of impacted third molars. A longitudinal prospective study on factors that affect postoperative recovery. Oral Surg Oral Med Oral Pathol. 1994;77(4):341-3.

16. Chuang SK, PerrottDH, Susarla SM, Dodson TB. Age as a risk factor for third molar surgery complications. J Oral Maxillofac Surg. 2007;65(9):1685-92.

17. Lago-Méndez L, Diniz-Freitas M, Senra-Rivera C, Gude-Sampedro F, Gándara Rey JM, García-García A. Relationships between surgical difficulty and postoperative pain in lower third molar extractions. J Oral Maxillofac Surg. 2007;65(5):979-83.

18. Bui CH, Seldin EB, Dodson TB. Types, frequencies, and risk factors for complications after third molar extraction. J Oral Maxillofac Surg. 2003;61(12):1379-89.

19. Haug RH, Perrott DH, Gonzalez ML, Talwar RM. The american association of oral and maxillofacial surgeons age-related third molar study. J Oral Maxillofac Surg. 2005;63(8):1106-14.

20. Power DJ, Sambrook PJ, Goss AN. The healing of dental extraction sockets in insulin-dependent diabetic patients: a prospective controlled observational study. Aust Dent J. 2019;64(1):111-6.

21. Chaparro-Avendaño AV, Pérez-García S, Valmaseda-Castellón E, Berini-Aytés L, Gay-Escoda C. Morbidity of third molar extraction in patients between 12 and 18 years of age. Med Oral Patol Oral Cir Bucal. 2005;10(5):422-31.

22. Chuang SK, Perrott DH, Susarla SM, Dodson TB. Risk factors for inflammatory complications following third molar surgery in adults. J Oral Maxillofac Surg. 2008;66(11):2213-8.

23. Malkawi Z, Al-Omiri MK, Khraisat A. Risk indicators of postoperative complications following surgical extraction of lower third molars. Med Princ Pract. 2011;20(4):321-5.

24. Fisher SE, Frame JW, Rout PG, McEntegart DJ. Factors affecting the onset and severity of pain following the surgical removal of unilateral impacted mandibular third molar teeth. Br Dent J. 1988;164(11):351-4. 
25. De Biase A, Mazzucchi G, Di Nardo D, Lollobrigida M, Serafini G, Testarelli L. Prevention of periodontal pocket formation after mandibular third molar extraction using dentin autologous graft: a split mouth case report. Case Rep Dent. 2020 Aug 31;2020:1762862. doi: 10:1155/2020/1762862.

\section{Dena Ali}

(Corresponding address) 